\title{
CANDIDURIA IN A PUBLIC HOSPITAL OF SÃO PAULO (1999-2004): CHARACTERISTICS OF THE YEAST ISOLATES
}

\author{
Elza Helena da SILVA, Luciana da Silva RUIZ, Flavia Emi MATSUMOTO, Marcos Ereno AULER, Mauro Cintra GIUDICE, Débora MOREIRA,
} Walderez SZESZS \& Claudete Rodrigues PAULA

\begin{abstract}
SUMMARY
The study involved 100 yeast isolates, obtained from urine samples provided by a Public Pediatric Hospital of São Paulo, Brazil, from 1999 to 2004. The most frequent species was Candida albicans, followed by C. tropicalis, C. glabrata and C. parapsilosis. In regard to virulence, 97\% of the isolates showed index 3 for proteinase and 63\% index 2 for phospholipase. The most frequent killer biotypes were 511 and 888 .
\end{abstract}

KEYWORDS: Candiduria; Nosocomial infections; Epidemiological markers.

\section{INTRODUCTION}

In the last 20 years, there has been a significant rise in the occurrence of nosocomial infections due to Candida genus yeasts. Lately, this increase has been much more associated to urinary tract infections ${ }^{5,10}$.

The incidence of fungemia and urinary tract infections is gradually on the rise and is an important public health problem. About 10 to $15 \%$ of urinary tract hospital infections are due to Candida spp., and its prevalence is still increasing ${ }^{2,47}$. Recent studies have shown that the rate of the urinary tract infection has increased from $0.9 / 1000$ to $2.0 /$ 1000 patients $^{1,3,33}$.

At the end of the 1980s, in the United States, 7\% of the total number of nosocomial urinary infections were caused by Candida species ${ }^{45}$.

A one-year yeast study conducted with 205 hospitalized patients, showed that, in cases of urinary infection, $22 \%$ of the isolates belonged to genus Candida ${ }^{20}$.

Recent studies related to urinary infections caused by Candida spp. have focused on specific predisposing conditions, however, particularly for children, candiduria frequency, characteristics and implications are still unknown ${ }^{24}$. Nevertheless, candiduria can be a precocious marker of a disseminated candidiasis, as demonstrated in a recent study of patients in a Surgical Intensive Care Unit precociously diagnosed with candiduria, who progressed to candidemia. Candiduria has developed in $1.3-10 \%$ of the patients who previously had funguria, and $0.4 \%$ of them evolved to death ${ }^{43}$.
Many researches showed that candiduria cases not reflect a disseminated candidiasis but colonization or lower urinary tract infection ${ }^{4,24}$. Often it is difficult to distinguish asymptomatic candiduria from bladder or renal infection. Urine cultures positive for Candida species have been noted in healthy men and women ${ }^{4,14}$.

In the present study, 100 yeast isolates obtained from children with candiduria were identified, and their virulence factors (proteinase and phospholipase) and killer phenotypes were investigated.

\section{MATERIAL AND METHODS}

Source of yeasts: This study involved 100 isolates of yeasts obtained from confirmed cases of candiduria in children (zero to seven years) hospitalized in the period from 1999 till 2004 in a Public Pediatric Hospital in São Paulo City, SP, Brazil. This tertiary care hospital, mainly attending a low-income population, has 90 patient beds.

Inclusion criterion: To be considered urinary yeast infection, the yeasts have to be isolated from urine samples with counts superior to $10^{4} \mathrm{UFC} / \mathrm{mL}$ for only one isolate and $10^{5} \mathrm{UFC} / \mathrm{mL}$ for more than one isolate $^{14,21}$.

Yeasts identification: The yeasts were identified according to their macroscopic, microscopic and physiological characteristics, according to KURTZMAN \& FELL ${ }^{23}$. For the identification of Trichosporon genus, the classification recommended by GUEHO et al. ${ }^{15}$ was used.

Proteinase research: Proteinase enzyme research was carried out according to RÜCHEL et al. ${ }^{37}$. The enzyme activity (PZ) was measured 


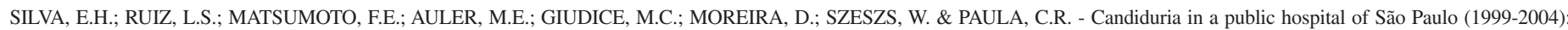
characteristics of the yeast isolates. Rev. Inst. Med. trop. S. Paulo, 49(6): 349-353, 2007.

according to PRICE et al. ${ }^{35}(\mathrm{Pz}=1$ - absence of enzyme activity $=$ index $1 ; 1.0<\mathrm{Pz} \geq 0.64$ - positive enzyme activity $=$ index $2 ; \mathrm{Pz}<0.64$ - strongly positive enzyme activity $=$ index 3 ). C. albicans pattern strain ICB-12A was used as a positive control.

Phospholipase analysis: Phospholipase enzyme testing was carried out according to PRICE et al. ${ }^{35}$. C. albicans pattern strain ICB-12A was used as a positive control.

Susceptibility to killer toxins: The Candida isolates' susceptibility to killer toxins was investigated by the technique described by POLONELLI et al. ${ }^{36}$. Nine pattern strains of killer-toxin producers, from Parma University, Italy, were used as a control.

\section{RESULTS}

The most frequent species were Candida albicans, $56.0 \%$, followed by C. tropicalis $(20.0 \%)$, C. glabrata (11.0\%), C. parapsilosis $(4.0 \%)$, C. Iusitaniae, C. guilliermondii, C. krusei (2.0\%) and Trichosporon asahii $(3.0 \%)$.
In regard to the production of extracellular enzymes, $84.0 \%$ of all the isolates showed strongly positive activity for proteinase (index 3 ), and $40.0 \%$ of these presented the same index for phospholipase activity. Of the C. albicans isolates, $98.2 \%$ were proteinase producers and $17.8 \%$ did not present phospholipase activity. All the non-albicans species showed proteinase production. Of the 43 non-albicans isolates, 24 $(55.8 \%)$ did not produce phospholipase. In regard to the three Trichosporon asahii isolates, it was observed that only one was a proteinase producer, while all of them did not produce phospholipase (Table 1).

The tests for susceptibility to killer toxins resulted in eight different biotypes. Of all 100 isolates, the most frequent biotypes were 511 $(63.0 \%)$ and $888(20.0 \%)$. The biotypes 513 and 555 were all $C$. albicans, while T. asahii revealed only biotype 888 (Table 2).

\section{DISCUSSION}

The frequency of urinary tract infection caused by yeasts has increased greatly over the last two decades due to the greater prevalence

Table 1

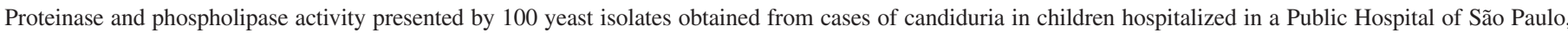
Brazil (1999-2004)

\begin{tabular}{|c|c|c|c|c|c|c|c|c|}
\hline \multirow{3}{*}{$\begin{array}{l}\text { Yeast } \\
\text { species }\end{array}$} & \multicolumn{6}{|c|}{ Enzymatic Indexes } & \multirow{2}{*}{\multicolumn{2}{|c|}{ TOTAL }} \\
\hline & \multicolumn{2}{|c|}{$\ln (\%)$} & \multicolumn{2}{|c|}{$2 \mathrm{n}(\%)$} & \multicolumn{2}{|c|}{$3 \mathrm{n}(\%)$} & & \\
\hline & $\mathrm{PA}$ & PPA & $\mathrm{PA}$ & PPA & $\mathrm{PA}$ & PPA & PA & PPA \\
\hline C. albicans (56) & $1(1.8)$ & $10(17.8)$ & $8(14.2)$ & $12(21.4)$ & $47(83.9)$ & $34(60.8)$ & $55(98.2)$ & $46(82.1)$ \\
\hline C. tropicalis (20) & - & $12(60)$ & $4(20)$ & $5(25)$ & $16(80)$ & $3(15)$ & $20(100)$ & $8(40.0)$ \\
\hline C. glabrata (11) & - & $6(54)$ & - & $2(18)$ & $11(100)$ & $3(28)$ & 11(100) & $5(45.4)$ \\
\hline C. parapsilosis (04) & - & $3(75)$ & - & $1(25)$ & $4(100)$ & - & $4(100)$ & $1(25)$ \\
\hline C. lusitaniae (02) & - & $1(50)$ & $1(50)$ & $1(50)$ & $1(50)$ & - & $2(100)$ & $1(50)$ \\
\hline C. krusei (02) & - & $2(100)$ & - & - & $2(100)$ & - & $2(100)$ & - \\
\hline C. guilliermondii(02) & - & - & - & $2(100)$ & $2(100)$ & - & $2(100)$ & $2(100)$ \\
\hline T. asahii (03) & $2(67)$ & $3(100)$ & - & - & $1(33)$ & - & $1(33)$ & - \\
\hline Total (\%) (100) & $3(3.7)$ & 37(37) & $13(13)$ & $23(23)$ & $84(84)$ & $40(40)$ & 97(97) & $63(63)$ \\
\hline
\end{tabular}

$\mathrm{PA}=$ proteolytic activity PPA $=$ phospholipase activity

Table 2

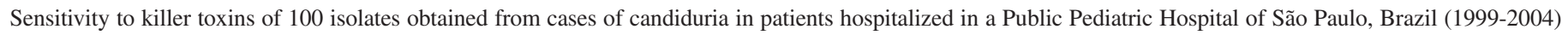

\begin{tabular}{|c|c|c|c|c|c|c|c|c|c|}
\hline \multirow[b]{2}{*}{ Species } & \multirow[b]{2}{*}{511} & \multirow[b]{2}{*}{513} & \multirow[b]{2}{*}{555} & \multicolumn{2}{|c|}{ Biotypes } & \multirow[b]{2}{*}{887} & \multirow[b]{2}{*}{888} & \multirow[b]{2}{*}{111} & \multirow[b]{2}{*}{ Total } \\
\hline & & & & 587 & 812 & & & & \\
\hline C. albicans & 46 & 01 & - & 01 & 01 & - & 05 & 02 & 56 \\
\hline C. tropicalis & 14 & - & 01 & 03 & - & - & 02 & - & 20 \\
\hline C. glabrata & 02 & - & - & 02 & - & 01 & 06 & - & 11 \\
\hline C. parapsilosis & - & - & - & 02 & - & - & 02 & - & 04 \\
\hline C. lusitaniae & - & - & - & - & - & 01 & - & 01 & 02 \\
\hline C. krusei & - & - & - & - & - & - & 02 & - & 02 \\
\hline C. guilliermondii & 01 & - & - & - & 01 & - & - & - & 02 \\
\hline T. asahii & - & - & - & - & - & - & 03 & - & 03 \\
\hline Total & $\begin{array}{c}\mathbf{6 3} \\
(63.0 \%)\end{array}$ & $\begin{array}{c}\mathbf{0 1} \\
(1.0 \%)\end{array}$ & $\begin{array}{c}\mathbf{0 1} \\
(1.0 \%)\end{array}$ & $\begin{array}{c}\mathbf{0 8} \\
(8.0 \%)\end{array}$ & $\begin{array}{c}\mathbf{0 2} \\
(2.0 \%)\end{array}$ & $\begin{array}{c}\mathbf{0 2} \\
(2.0 \%)\end{array}$ & $\begin{array}{c}\mathbf{2 0} \\
(20.0 \%)\end{array}$ & $\begin{array}{c}\mathbf{0 3} \\
(3.0 \%)\end{array}$ & $\begin{array}{c}100 \\
(100.0 \%)\end{array}$ \\
\hline
\end{tabular}


of prolonged hospitalization, patients with advanced age, immunocompromised patients; use of antibiotics; prophylaxis by antifungal agents; use of urinary catheters; urinary tract surgical manipulation and, especially, longer stays in intensive care units ${ }^{3}$. Catheterized patients are at special risk, since around $26 \%$ of the urinary tract infections are caused by fungus ${ }^{42}$.

EMORI \& GAYNES ${ }^{9}$ and JARVIS ${ }^{17}$ reported that $25 \%$ of the urinary tract infections are due to Candida genus yeasts. Candida albicans accounts for 40 to $65 \%$ of the fungi isolated from candiduria cases ${ }^{31}$. However, there has been an increase in the incidence of other species, and recently it has been observed that the urinary tract is more frequently colonized by non-albicans species than are other sites. The non-albicans species include most notably C. glabrata, C. tropicalis, C. parapsilosis, C. krusei, C. lusitaniae and Trichosporon spp. ${ }^{33}$.

A survey conducted from 1990 to 1991 of the aetiological agents in urine collected in a tertiary care hospital found a $34 \%$ rise in nonalbicans species and a $11 \%$ decrease in C. albicans $^{31}$. KRCMÉRY \& KOVACICOVÁ $^{22}$, in a 10 -year study, also verified that although $C$. albicans was still the most frequently isolated species, there had been an increase of non-albicans species from $1 \%$ in 1991 to $46.3 \%$ in 1998 . Candida albicans was identified in $61.6 \%$ of all the fungemia cases, followed by C. parapsilosis $(9.9 \%)$, C. krusei $(5.8 \%)$, C. tropicalis (4.1\%) and C. glabrata (3.2\%).

In the present study, $C$. albicans was the species most frequently isolated, representing $56 \%$ of all the yeasts. However, other species were isolated and the second-most frequent was C. tropicalis $(20 \%)$, followed by C. glabrata (11\%). During the period from 1998 to 1999 , WEINBERGER et al. ${ }^{47}$ studied 751 patients with candiduria and found that $C$. albicans was the most common species, with an incidence of $56.4 \%$, followed by C. tropicalis (19\%) and C. glabrata (15\%). Other recent studies have also observed that $C$. albicans is still the most commonly isolated species, followed by $C$. tropicalis ${ }^{20,27,30}$. Lately, studies have shown that $C$. glabrata is the second most isolated species in candiduria cases ${ }^{19,40}$.

Significant geographic variations on the etiological pattern of invasive Candida spp. infections have been reported in various countries. In North America there is a predominance of C. glabrata among non-albicans species, in South America, however, $C$. parapsilosis and C. tropicalis are the predominant ones ${ }^{8}$.

These data have been confirmed by statistical studies performed in South America that have shown the relevance of invasive infections due to $C$. parapsilosis and $C$. tropicalis $^{12,13,27,39}$. The reasons for this inversion of the species' distribution pattern have not yet been completely elucidated, but may be related to the microorganisms virulence potential and resistance to antifungals ${ }^{8}$.

For the Candida genus, one of the most studied virulence factors is the production of extracellular enzymes, such as the secreted aspartyl proteinase (SAPs) that hydrolyse peptide bonds, along with the phospholipases, which hydrolyse phospholipides ${ }^{29}$.

Various studies have demonstrated that Candida albicans and other species are proteinase and phospholipase producers, underscoring the role that these enzymes play as virulence determinants, regardless of the site from which they are isolated ${ }^{26,27,34,39}$. According to IBRAHIM et al. ${ }^{16}$, Candida albicans seems to be the only Candida species which produces phospholipase in vitro. That study also evaluated the ability of various Candida spp. species to produce phospholipase, and found that while $79 \%$ of the $41 \mathrm{C}$. albicans isolates produced this enzyme, this was not the case for any of the C. tropicalis, $C$. glabrata or $C$. parapsilosis isolates. MATSUMOTO et al. ${ }^{27}$, studying the production of phospholipase in Candida obtained from catheter and blood, found that while $87.5 \%$ of the $C$. albicans isolates produced this enzyme, only three non-albicans isolates did. KANTARCIOGLU et al. ${ }^{18}$ verified that while $62.1 \%$ of the non-albicans isolates showed phospholipase activity, $93.3 \%$ of the C. albicans isolates did. RUIZ et al. ${ }^{39}$ observed phospholipase production in $48.3 \%$ of C. albicans isolates and in $2.7 \%$ of the non-albicans ones.

In the present study, a higher phospholipase activity was also observed for C. albicans ( $82 \%$ ), in comparison to non-albicans (41\%) and T. asahii (33\%) isolates. This enzyme may also be used as a marker in the diagnosis of candidiasis ${ }^{11}$.

In regard to proteinase, the enzymatic activity of $C$. albicans isolates ranged from $62.5 \%$ to $100 \%$. Experimentally, mutants deficient in terms of proteinase production seem to be less virulent to animals than their proteolytic relatives ${ }^{46}$.

The literature has demonstrated distinct levels of proteinase production by different $C$. albicans isolates and different Candida species. Moreover, a correlation has been demonstrated between the level of proteinase production and virulence by species, in descending order: C. albicans, C. tropicalis, C. parapsilosis, C. krusei, C. glabrata and $C$. guilliermondii ${ }^{25,37,38}$.

SILVA et al. ${ }^{42}$ isolated C. albicans from the oral mucosa of patients with AIDS and verified proteinase production in $100 \%$ of the isolates. MATSUMOTO et al. ${ }^{27}$ studied 80 Candida isolates obtained from blood and catheter and observed that $81.3 \%$ presented proteolytic activity. A study performed by RUIZ et al. ${ }^{39}$ demonstrated a strong proteinase activity in Candida species: $100 \%$ for C. albicans and $97.8 \%$ for nonalbicans, isolated from blood. In the present study, $98 \%$ of the $C$. albicans and $100 \%$ of non-albicans species presented strong proteinase activity.

Among the 100 isolates of the present study eight different killer biotypes were found. The biotype most frequently encountered was 511 (63\% of all the isolates), representing $82.1 \%$ of the Candida albicans and $70.0 \%$ of the Candida tropicalis. Biotype 888, the secondmost frequent, was observed in Candida glabrata (54.5\%) and Candida parapsilosis $(50.0 \%)$.

RUIZ et al..$^{39}$ demonstrated six killer biotypes, while POLONELLI et $a l .{ }^{36}$, CANDIDO et al. ${ }^{6}$ and MATSUMOTO et al. ${ }^{27}$ registered, respectively, 25, 23 and seven different biotypes. These differences might be related to the variety of anatomical sites from which the yeast samples were taken. Moreover, some studies have found a lower number of killer biotypes than were encountered in these studies ${ }^{7,32}$.

The most frequent biotypes, 511 and 888 , were also prevalent in 


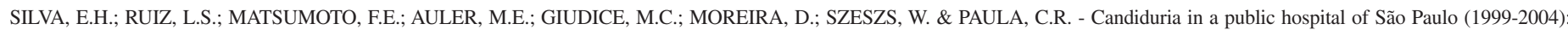
characteristics of the yeast isolates. Rev. Inst. Med. trop. S. Paulo, 49(6): 349-353, 2007.

$89.6 \%$ of the Candida species isolated from the blood of hospitalized patients ${ }^{25}$, so they are not restricted only to the urine.

According to MORACE et al. ${ }^{28}$, the use of the killer system for differentiating isolates of pathogenic yeast species can be a useful method for dealing with the nosocomial infections caused by these microorganisms.

\section{RESUMO}

\section{Candiduria em hospital público de São Paulo (1999-2004): características das leveduras isoladas}

Estudou-se 100 amostras de leveduras, isoladas de urina, provenientes de Hospital Público Infantil de São Paulo Brasil, no período de 19992004. A espécie mais freqüente foi Candida albicans, seguida de $C$. tropicalis, C. glabrata e C. parapsilosis. Em relação à virulência, 97\% dos isolados apresentaram índice 3 para proteinase e, $63 \%$ índice 2 para fosfolipase. Os biótipos "killer" mais freqüentes foram o 511 e 888.

\section{REFERENCES}

1. ALMIRANTE, B.; RODRIGUEZ, D.; PARK, B.J. et al. - Epidemiology and predictors of mortality in cases of Candida bloodstream infection: results from populationbased surveillance, Barcelona, Spain, from 2002 to 2003. J. clin. Microbiol., 43: 1829-1835, 2005.

2. ALVAREZ-LERMA, F.; NOLLA-SALAS, J.; LEON, C. et al. - Candiduria in critically ill patients admitted to intensive care medical units. Intensive Care Med., 29: 10691076, 2003.

3. BINELLI, C.A.; MORETTI, M.L.; ASSIS, R.S. et al. - Investigation of the possible association between nosocomial candiduria and candidaemia. Clin. Microbiol. Infect., 12: 538-543, 2006.

4. BODEY, G.P. - Candidiasis - pathogenesis, diagnosis and treatment. New York, Raven Press, 1993.

5. BRITO, L.R.; GUIMARÃES, T.; NUCCI, M. et al. - Clinical and microbiological aspects of candidemia due to Candida parapsilosis in Brazilian tertiary care hospitals. Med. Mycol., 44: 261-266, 2006.

6. CANDIDO, R.C.; FISCHMAN, O.; ZAROR, L. \& ITO, I.Y. - Diferenciação de cepas de Candida albicans pelo sistema killer. Rev. Soc. bras. Med. trop., 28: 321-324, 1995.

7. CARAMALAC, D.A. - Ocorrência de leveduras em parturientes e recém-nascidos: tipagem das amostras de Candida albicans. São Paulo, 1995. (Dissertação de Mestrado - Instituto de Ciências Biomédicas II, Universidade de São Paulo).

8. COLOMBO, A.L. \& GUIMARÃES, T. - Epidemiology of hematogenous infections due to Candida spp . Rev. Soc. bras. Med. trop., 36: 599-607, 2003.

9. EMORI, T.G. \& GAYNES, R.P. - An overview of nosocomial infections, including the role of microbiology laboratory. Clin. Microbiol. Rev., 6: 428-442, 1993.

10. FAULKNER, B.; CHAKSUPA, D.; MALAS, A. \& ROSENCRANCE, J.G. - Persistent candiduria complicating intraureteral stenting: a case report and review of the literature. W. Va. med. J., 99: 25-27, 2003.

11. GHANNOUM, M.A. - Potential role of phospholipases in virulence and fungal pathogenesis. Clin. Microbiol. Rev, 13: 122-143, 2000.

12. GODOY, P.; TIRABOSCHI, I.N.; SEVERO, L.C. et al. - Species distribution and antifungal susceptibility profile of Candida spp. bloodstream isolates from Latin American hospitals. Mem. Inst. Oswaldo Cruz, 98: 401-405, 2003.
13. GOLDANI, L.Z. \& MARIO, P.S. - Candida tropicalis fungemia in a tertiary care hospital. J. Infect., 46: 155-160, 2003.

14. GOLDBERG, P.K.; KOZINN, P.G.; WISE, G.J. et al. - Incidence and significance of candiduria. J. Amer. med. Ass., 241: 582-584, 1979.

15. GUÉHO, E.; SMITH, M.T.; DE HOOG, G.S. et al. - Contributions to a revision of the genus Trichosporon. Antonie v. Leeuwenhok., 61: 289-316, 1992.

16. IBRAHIM, A.S.; MIRBORD, F.; FILLER, S.G. et al. - Evidence implicating phospholipase as a virulence factor of Candida albicans. Infect. Immun., 63: 19931998, 1995.

17. JARVIS, W.R. - Epidemiology of nosocomial fungal infections, with emphasis on Candida species. Clin. infect. Dis., 20: 1526-1530, 1995.

18. KANTARCIOGLU, A.S. \& YUCEL, A. - Phospholipase and protease activities in clinical Candida isolates with reference to the sources of strains. Mycoses, 45: 160-165, 2002.

19. KAUFFMAN, C.A.; VAZQUEZ, J.A.; SOBEL, J.D. et al. - The prospective multicenter surveillance study of funguria in hospitalized patients. National Institute for Allergy and Infectious Diseases (NIAID) Mycoses Study Group. Clin. infect. Dis., 30: 1418,2000 .

20. KOBAYASHI, C.C.B.A.; FERNANDES, O.F.L.; MIRANDA, K.C.; SOUZA, E.D. \& SILVA, M.R.R. - Candiduria in hospital patients: a study prospective. Mycopathologia., 158: 49-52, 2004.

21. KOZINN, P.H.; TASCHDJIAN, C.L.; GOLDBERG, P.K. et al. - Advances in the diagnosis of renal candidiasis. J. Urol., 116: 778-780, 1976.

22. KRCMÉRY Jr., V. \& KOVACICOVÁ, G. - Longitudinal 10-year prospective survey of fungemia in Slovak Republic: trends in etiology in 310 episodes. The Slovak Fungaemia Study Group. Diagn. Microbiol. infect. Dis., 36: 7-11, 2000.

23. KURTZMAN, C.P. \& FELL, J.W. - The yeasts: a taxonomic study. New York, Elsevier, 1998.

24. LUNDSTROM, T. \& SOBEL, J. - Nosocomial Candiduria: a review. Clin. infect. Dis. 32: 1602-1607, 2001.

25. MacDONALD, F. - Secretion of inducible proteinase by pathogenic Candida species. Sabouraudia, 22: 79-82, 1984

26. MAFFEI, C.M.; PAULA, C.R.; MAZZOCATO, T.S. \& FRANCESCHINI, S. - Phenotype and genotype in $C$. albicans strains delayed from pregnant women with recurrent vaginitis. Mycopathologia (Den Haag), 137: 87-94, 1997.

27. MATSUMOTO, F.E.; GANDRA, R.F.; RUIZ, L.S. et al. - Yeasts isolated from blood and catheter in children from a Public Hospital of São Paulo, Brazil. Mycopathologia, 154: 63-69, 2002.

28. MORACE, G.; ARCHIBUSACCI, C.; SESTITO, M. \& POLONELLI, L. - Strain differentiation of pathogenic yeast by the "killer" system. Mycopathologia (Den Haag), 84: 81-85, 1984.

29. NAGLIK, J.; ALBRECHT, A.; BADER, O. \& HUBE, B. - Candida albicans proteinases and host/ pathogen interactions. Cell Microbiol., 10: 915-926, 2004

30. NUCCI, M. - Candiduria in hospitalized patients: a review. Braz. J. infect. Dis., 4: 168 $172,2000$.

31. OCHIPINTI, D.J.; GUBBINS, P.O.; SCHRECKENBERGER, P. \& DANZIGER, L.H. Frequency pathogenicity and microbiologic outcome of non-Candida albicans candiduria. Europ. J. clin. Microbiol. infect. Dis., 13: 459-467, 1994.

32. OLIVEIRA, E.E.; SILVA, S.C.; SOARES, A.J. et al. - Toxinas "killer" e produção de enzima por isolados da mucosa bucal de pacientes com câncer. Rev. Soc. bras. Med. trop., 31: 523-527, 1998. 


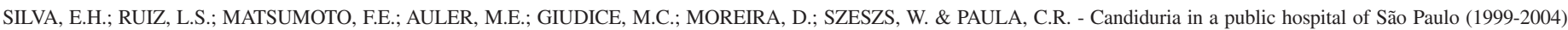
characteristics of the yeast isolates. Rev. Inst. Med. trop. S. Paulo, 49(6): 349-353, 2007.

33. OLIVEIRA, R.D.; MAFFEI, C.M. \& MARTINEZ, R. - Infecção urinária hospitalar por leveduras do gênero Candida sp. Rev. Ass. méd. bras., 47: 321-325, 2001.

34. PAULA, C.R.; SAMPAIO, M.C.C.; BIRMAN, E.G. \& SIQUEIRA, A.M. - Oral yeasts in patients with bucal cancer before and during radiotherapy. Mycopathologia (Den Haag), 112: 119-124, 1990.

35. PRICE, M.F.; WILKINSON, I.D. \& GENTRY, L.O. - Plate method for detection of phospholipase in Candida albicans. Sabouraudia, 20: 7-14, 1982.

36. POLONELLI, L.; ARCHIBUSACCI, C.; SESTITO, M. \& MORACE, G. - "Killer" system: a simple method for differentiating Candida albicans strains. J. clin. Microbiol., 17: $774-780,1983$.

37. RÜCHEL, R.; TEGELER, R. \& TROST, M.A. - Comparison of secretory proteinases from different strains of Candida albicans. Saboraudia, 20: 233-244, 1982.

38. RÜCHEL, R.; UKLEMANN, K. \& BONING, B. - Secretion of acid proteinases by different species of the genus Candida. Zbl. Bakt. Hyg. I. Abt. Orig., 255: 537$548,1983$.

39. RUIZ, L.S.; SUGIZAKI, M.F.; MONTELLI, A.C. et al. - Fungemia by yeast in Brazil: occurrence and phenotypic study of strains isolated at the Public Hospital, Botucatu, São Paulo. J. Mycol. Med., 15: 13-21, 2005.

40. SAFDAR, N.; SLATTERY, W.R.; KNASINSKI, V. et al. - Predictors and outcomes of candiduria in renal transplant patients. Clin. infect. Dis., 40: 1413-1421, 2005.

41. SELLAMI, A.; SELLAMI, H.; MAKNI, F. et al. - La candidurie en milieu de réanimation: signification et interêt de la numération des levures dans les urines. Ann. français. Anesth. Reanim., 25: 584-588, 2006.
42. SILVA, M.R.R., COSTA, M.R., MIRANDA, A.T.B ; FERNANDES, O.F.L. \& PAULA, C.R. - Evaluation of Etest and macrodilution broth method for antifungal susceptibility testing of Candida sp. strains isolated from oral cavities of AIDS patients. Rev. Inst. Med. trop. S. Paulo., 44: 121-125, 2002.

43. SIMPSON, C.; BLITZ, S. \& SHAFRAN, S.D. - The effect of current management on morbidity and mortality in hospitalised adults with funguria. J. Infect., 49: 248$252,2004$.

44. SOBEL, J.D.; KAUFFMAN, C.A.; McKINSEY, D. et al. - Candiduria a randomized double-blind study of treatment with fluconazole and placebo. The National Institute of Allergy and Infectious Diseases (NIAID) Mycoses Study Group. Clin. infect. Dis., 30: 19-24, 2000.

45. VOSS, A.; HOLLIS, R.J.; PFALLER, M.A.; WENZEL, R.P. \& DOEBBELING, B.N. Investigation of the sequence of colonization and candidemia in nonneutropenic patients J. clin. Microbiol., 32: 975-980, 1994.

46. WALTHER, T.H.; RYTTER, M.; SHONBORN, C. \& HAUSTEIN, U.F. - Differences in the intracellular killing of proteinase-positive and proteinase negative C. albicans strains by granulocytes. Mykosen., 29: 154-161, 1986.

47. WEINBERGER, M.; SWEET, S.; LEIBOVICI, L.; PITLIK, S.D. \& SAMRA, Z.J Correlation between candiduria and departmental antibiotic use. J. Hosp. infect., 53: 183-186, 2003.

Received: 27 October 2006

Accepted: 23 July 2007 